\title{
Effect of post-exercise ingestion of different molecular weight carbohydrate solutions. Part 1: The glucose and insulin response
}

\author{
Anthony L Almada ${ }^{1 *}$, Leighsa E Van Eck², Meena Shah², Margaret T Jones ${ }^{3}$, Andrew Jagim ${ }^{4}$, Ryan Dalton ${ }^{5}$, \\ Joel Mitchell2, Jonathan M Oliver² \\ From The Twelfth International Society of Sports Nutrition (ISSN) Conference and Expo \\ Austin, TX, USA. 11-13 June 2015
}

\section{Background}

Post-exercise ingestion of a high molecular weight (HMW) carbohydrate $(\mathrm{CHO})$ solution has been shown to result in greater rates of muscle glycogen synthesis, attributed, in part, to the higher rates of gastric emptying compared to a low molecular weight (LMW) $\mathrm{CHO}$ solution. Given the higher rate of gastric emptying, a more rapid rise of glucose and insulin would be expected. However, differences have been reported in the pattern and time course of the subsequent insulin and glucose responses following ingestion. These differences have been attributed to timing and technique (venous vs. arterialized venous) of blood sampling. Thus, the current study sought to examine differences in the glucose, insulin, and glucagon response to postexercise ingestion of a HMW and LMW CHO solution.

\section{Methods}

Sixteen resistance trained men (mean \pm SD; $23 \pm 3$ years; $176.7 \pm 9.8 \mathrm{~cm} ; 88.2 \pm 8.6 \mathrm{~kg} ; 12.1 \pm 5.6 \%$ fat) participated in this double-blind, placebo-controlled, randomized crossover study, which consisted of three testing sessions, each separated by one week. $\mathrm{VO}_{2} \max \left(37.4 \pm 4.3 \mathrm{ml} \cdot \mathrm{kg} \cdot \mathrm{min}^{-1}\right)$ was determined prior to testing session 1 . In sessions 1-3, subjects completed a glycogen depleting cycling bout of 60 minutes at $70 \% \mathrm{VO}_{2}$ max, followed by six, one-minute sprints at $120 \% \mathrm{VO}_{2}$ max. Immediately post-exercise subjects ingested a placebo (PLA), or a LMW or HMW CHO solution (10\%) providing $1.2 \mathrm{~kg} \cdot \mathrm{bw}^{-1} \mathrm{CHO}$; assigned randomly. Blood was sampled prior to ingestion and every ten minutes for 120 minutes post-ingestion. A two-factor

\footnotetext{
${ }^{1}$ Vitargo Global Sciences, LLC, Dana Point, CA 92629, USA

Full list of author information is available at the end of the article
}

repeated measures ANOVA was used to determine differences among treatments $(\mathrm{p} \leq 0.05)$.

\section{Results}

Post-exercise ingestion of the LMW and HMW CHO solutions caused an increase in plasma glucose and insulin at 10 minutes. Glucose remained elevated in LMW until 60 minutes; and 70 minutes in HMW. The difference between HMW and LMW at that time approached significance (LMW, $4.7 \pm 0.3 \mathrm{mmol} \cdot \mathrm{L}^{-1}$; HMW, $5.2 \pm 0.3 \mathrm{mmol}$. $\left.\mathrm{L}^{-1} ; \mathrm{p}=0.086\right)$. Insulin remained elevated throughout blood sampling. Peak plasma insulin occurred at $40 \mathrm{~min}-$ utes (LMW, $50.0 \pm 7.1 \mu \mathrm{IU} \cdot \mathrm{L}^{-1}$; HMW, $49.8 \pm 8.3 \mu \mathrm{IU}$. $\mathrm{L}^{-1}$ ). Plasma glucagon declined following $\mathrm{CHO}$ ingestion with a more rapid difference following LMW (20 minutes) than HMW (30 minutes) CHO solution. However, no differences were noted between $\mathrm{CHO}$ treatments. Glucagon achieved a peak value of $38.7 \pm 5.5 \mathrm{ng} \cdot \mathrm{L}-1$ after ingestion of the PLA, while the lowest values observed following ingestion of the LMW and HMW CHO solutions were $12.0 \pm$ $1.7 \mathrm{ng} \cdot \mathrm{L}^{-1}$ and $11.5 \pm 1.4 \mathrm{ng} \cdot \mathrm{L}^{-1}$, respectively.

\section{Conclusions}

These data suggest that when venous blood is sampled, ingestion of HMW and LMW CHO solutions providing $1.2 \mathrm{~kg} \cdot \mathrm{bw}^{-1} \mathrm{CHO}$ result in similar responses in glucose, insulin, and glucagon. Further study is needed to determine the effect on subsequent performance.

\section{Acknowledgements}

This work was supported in part by Vitargo Global Sciences, LLC.

\section{Authors' details}

'Vitargo Global Sciences, LLC, Dana Point, CA 92629, USA. ²Department of Kinesiology, Texas Christian University, Fort Worth, TX 76129, USA. ${ }^{3}$ Health 
and Human Performance Division, George Mason University, Fairfax, VA 22030, USA. ${ }^{4}$ Exercise \& Sport Science Department, University of Wisconsin, La Crosse, La Crosse, WI 54601, USA. ${ }^{5}$ Department of Health and Kinesiology, Texas A\&M University, College Station, TX 77843, USA.

Published: 21 September 2015

doi:10.1186/1550-2783-12-S1-P30

Cite this article as: Almada et al:: Effect of post-exercise ingestion of different molecular weight carbohydrate solutions. Part 1: The glucose and insulin response. Journal of the International Society of Sports Nutrition 2015 12(Suppl 1):P30.

Submit your next manuscript to BioMed Central and take full advantage of:

- Convenient online submission

- Thorough peer review

- No space constraints or color figure charges

- Immediate publication on acceptance

- Inclusion in PubMed, CAS, Scopus and Google Scholar

- Research which is freely available for redistribution

Submit your manuscript at www.biomedcentral.com/submit 